\title{
Bacterial Load Assessment of some Food Items Sold in Street in Woldia Town, North-East Ethiopia
}

\author{
Kindu Alem* \\ Department of Biology, Natural and Computational Sciences Faculty, Woldia University, Woldia, P.O.Box 400, \\ Ethiopia.
}

\begin{abstract}
Infectious diseases due to contaminated street vended food items has happened to an essential concern and public health issue in low socio-economic status individuals. The goal of this study was to evaluate bacterial quality and safety of some food items sold in street based on aerobic mesophilic bacteria, Salmonella, Staphylococcus aureus and Escherichia coli in Woldia town. Cross-sectional study was performed on some selected street vended foods from March 2019 to May 2019 in Woldia town. A total of 36 ready-to-eat food samples such as 'Sambussa', 'Bonbolino' and 'Ambasha' were collected for microbial analysis. Finding of the study indicates that $32(88.9 \%)$ of the vendors were females, $\mathbf{2 8}(\mathbf{7 7 . 7 \%})$ handled food with bare hands, $\mathbf{2 8}(\mathbf{7 7 . 7 \%})$ vendors were washing their hands after toilet. The mean total count of aerobic mesophilic bacteria, Salmonella, Staphylococcus aureus and Escherichia coli was $4.5 \times 102 \pm 5.2 \times 10^{1} \mathrm{CFUg}^{-1}, 1.5 \times 102 \pm 4.5 \times 10^{1} \mathrm{CFUg}^{-1}, 1.1 \times 102 \pm 1.4 \times 10^{1} \mathrm{CFUg}^{-1}$ and $2 \times 102 \pm 3.4 \times 10^{1}$ $\mathrm{CFUg}^{-1}$, respectively. The dominant bacterial isolate from the street vended foods was Escherichia coli (53.5\%), followed by Salmonella (24.1\%) and Staphylococcus aureus (22.4\%). The result of this study demonstrates the non hygienic practices of the vendors in street vended foods showed high bacterial load. Therefore, the street vended foods were contaminated with food borne pathogenic bacteria that can create a potential risk to public health in the study area. In general, the bacterial quality of the food quality sold in street in Woldia town was very poor and needs especial attention to avoid bacterial contamination.

Keywords: Street-vended food, Staphylococcus aureus, Salmonella, Escherichia coli
\end{abstract}

*Correspondence: kindualem@gmail.com; +251918712953

(Received: May 19, 2020; accepted: August 19, 2020)

Citation: Alem K. Bacterial Load Assessment of some Food Items Sold in Street in Woldia Town, North-East Ethiopia. J Pure Appl Microbiol. 2020;14(3):1845-1854. doi: 10.22207/JPAM.14.3.23

(C) The Author(s) 2020. Open Access. This article is distributed under the terms of the Creative Commons Attribution 4.0 International License which permits unrestricted use, sharing, distribution, and reproduction in any medium, provided you give appropriate credit to the original author(s) and the source, provide a link to the Creative Commons license, and indicate if changes were made. 


\section{INTRODUCTION}

In low income countries foods sold in the street by food vendors prepared at home and consumed on the street without further preparation ${ }^{1}$. In developing countries where there is high unemployment, low salary incomes, little work chance and where urbanization is taking place, consumption of street vended food items is common ${ }^{2}$. Both food venders and consumers are beneficiary from the street vended foods. Street food items are accessible, cheap, and nutritionally-balance and also supply a base of income, opportunity of self-employment and chance to develop business skill with low capital investments to the vendors ${ }^{3}$. Foods vended in the street are predisposed to contaminations since they are exposed to dust and are often not covered. Consuming unsafe food poses an important community health risk in both developed and developing countries ${ }^{4}$. Diseases due to contaminated food are still a common problem and causes mortality and morbidity in the community. Transmission of food related diseases due to lack of hygiene of food handlers is a common worldwide problem and a wide range of enteric pathogenic microorganisms might be carried by food handlers and implicate infections in the public ${ }^{5}$. A number of scholars reported that food borne infections have been alarmingly increasing throughout the world. These reports have shown that inadequate food hygiene and safety practices during food handling, preparation and serving are the major causes ${ }^{6}$. Even if there is a well awareness about diseases transmitted because of consumption of contaminated street vended food items, most of the consumers do not give attention these health hazards ${ }^{7}$. Several studies have showed that different types of disease causing microorganisms such as Bacillus cereus, Staphylococcus aureus, Salmonella spp and E. coli have been obtained in various types foods sold in the street ${ }^{8}$. Every year, food borne infections cause the suffering of millions of people throughout the world 9 . A report done in 2005 only showed that diarrheal diseases cause for the death of 1.8 million ${ }^{10}$. The National Hygiene and Sanitation Strategy program in Ethiopia reported that about $60 \%$ of the infection load is related to poor hygiene and sanitation practice of the consumers ${ }^{11}$. Salmonella, Shigella and related food borne infectious causing microorganisms were identified in the foods sold in the street and become serious health problem in Ethiopia. Diarrheal disease represents the second leading cause of death in Ethiopia $^{12,13}$. Uses of street foods are nowadays common in different towns of Ethiopia and it is observed in areas of many people found such as bus stations, schools and other places. The low income category of the people commonly consumes foods sold in the street in Woldia town. However, the awareness of the consumers on the safety and microbial load of the food items sold in the street and related factors in this study area are limited.

The main purpose of the present study was to investigate the microbial safety of street vended foods and food handling practice of the venders in Woldia town, North East Ethiopia.

\section{MATERIALS AND METHODS}

\section{The study area}

This study was done in Woldia, the main town of North Wollo, located $530 \mathrm{~km}$ North East of Addis Ababa, the capital city of Ethiopia (Fig. 1). The town's geographical coordination is $11^{\circ} 50^{\prime} \mathrm{N}$ latitude and $39^{\circ} 36^{\prime} \mathrm{E}$ longitude. The town has an elevation of $2112 \mathrm{~m}$ above sea level.

\section{Study design}

A cross sectional study design was conducted in Woldia town from February to June 2019 to examine the bacteriological quality and handling practices of food sold in the street such as 'Sambussa', 'Bonbolino' and 'Ambasha' vended at Gonderber, Mugad, Menehariya and Piazza. In the present study the study population was randomly selected street food venders in Woldia town.

\section{Sampling technique}

Random and nonrandom sampling techniques were used to select representative street food sellers in the study area. Four common street food vending sites such as Gonderber, Mugad, Menehariya and Piazza were selected purposefully. A Total of 36 samples of food items sold in the street which consist of 12'Sambussa', 12 'Bonbolino' and 12'Ambasha' were selected by random sampling technique and taken into microbiology laboratory of Woldia University for bacteriological load analysis.

Socio-demographic data collection Socio-demographic data and personal 
hygiene practices of the street food vendors from 36 venders were selected by using random sampling technique. The data were collected by face to face interview method using semistructured questionnaire and an observation checklist.

\section{Sample collection}

Three most street vended food stuffs, namely 'Sambussa' 'Bonbolino' and 'Ambasha' were selected for bacteriological analysis and randomly bought from street food vendors. The food items for laboratory analysis were aseptically collected from street food sellers by using sterile glass material and immediately stored in icebox. All the collected food items were taken to microbiology laboratory of Woldia University for bacteriological analysis. The collected food samples were placed in the refrigerator at $4^{\circ} \mathrm{C}$ till bacteriological analysis was carried out. Bacterial analysis was conducted within one to three hours after sample collection.

\section{Bacteriological methods \\ Food sample preparation}

For microbiological analysis $10 \mathrm{~g}$ of each food samples namely 'Sambussa', 'Bonbolino' and 'Ambasha' were homogenized in $90 \mathrm{ml}$ buffered peptone water. Then after, the food sample homogenates were processed to serial dilutions of $10^{-2}, 10^{-3}, 10^{-4}$ and $10^{-5}$ of all food items, the suspected bacterial load of $0.1 \mathrm{ml}$ dilutions were transferred to plates and spread by L-shaped glass tube to plates and incubated at $37^{\circ} \mathrm{C}$ for 48 hours, finally the load of bacteria counted by colony counter. The counted colonies were expressed in colony forming units per gram $\left(\mathrm{CFUg}^{-1}\right)$.

\section{Microbial enumeration}

\section{Aerobic mesophilic bacteria}

The pour plate technique on plate count agar (PCA) (Oxoid Ltd, United Kingdom) was used to count aerobic mesophilic bacteria. A homogenized food sample of $0.1 \mathrm{ml}$ was inoculated onto plate count agar in triplicate and the plates

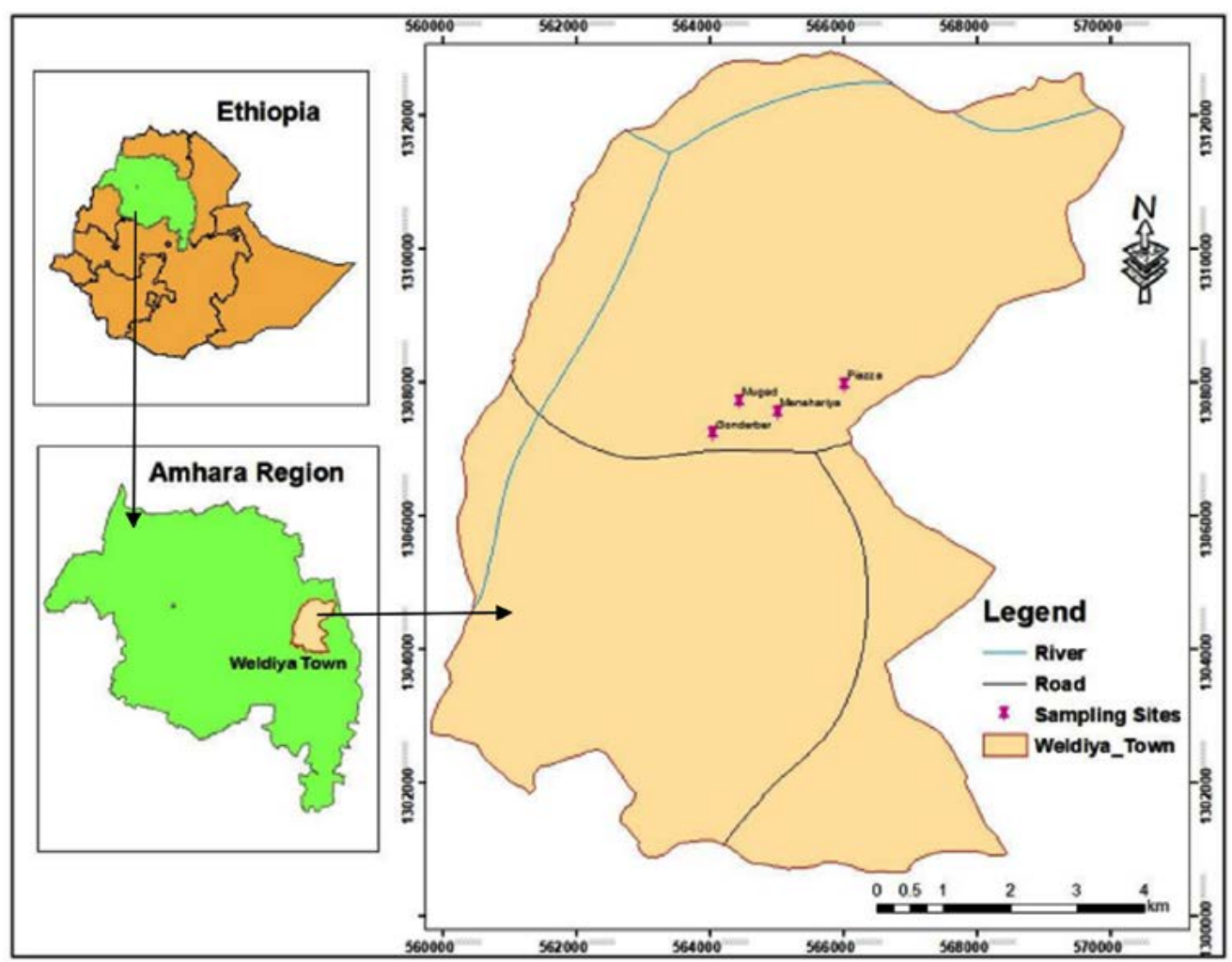

Fig. 1. Street food sampling sites in Woldia town 
were incubated aerobically at $37^{\circ} \mathrm{C}$ for $48 \mathrm{hrs}$. All plates showing colony counts between 30 and 300 were selected and their colony forming unit per gram of food item $\left(\mathrm{CFUg}^{-1}\right)$ were calculated by multiplying by the dilution factor.

\section{Isolation of Salmonella}

To detect Salmonella, 10g of food sample was homogenized in $90 \mathrm{ml}$ buffered peptone water and shook for 2-3 minutes using shaker (STUART, UK) to prepare homogenate dilution. A serial dilutions of $10^{-2}, 10^{-3}, 10^{-4}$ and $10^{-5}$ were underwent from homogenate food sample and $0.1 \mathrm{ml}$ dilutions were transferred to xylose-lysine-deoxycholate (XLD) agar and spread by L-shaped glass tube to plates and incubated at $37^{\circ} \mathrm{C}$ for 48 hours. Then black centered pink colonies were enumerated using colony counter (STUART SCIENTIFIC, UK). Colony forming unit per gram of food item $\left(\mathrm{CFUg}^{-1}\right)$ was determined by multiplying with the dilution factor.

\section{Isolation of Staphylococcus aureus}

For Staphylococcus aureus, 10g of food sample was homogenized in $90 \mathrm{ml}$ buffered peptone water and shook for 2-3 minutes using shaker (STUART, UK) to prepare homogenate dilution. A serial dilutions of $10^{-2}, 10^{-3}, 10^{-4}$, and $10^{-5}$ were underwent from homogenate food sample and $0.1 \mathrm{ml}$ dilutions were transferred to sterile molten Mannitol salt agar (BLULUX) petri plate and then incubated at $37^{\circ} \mathrm{C}$ for 48 hours. Finally, due to Mannitol fermentation yellow to orange colonies surrounded by yellow zone was enumerated using colony counter (STUART SCIENTIFIC, UK) and the obtained data was recorded as colony forming unit per gram (CFUg ${ }^{-1}$ ) of all food items.

Isolation of $E$. coli

Ten gram of food sample was homogenized in $90 \mathrm{ml}$ buffered peptone water and shook for 2-3 minutes using shaker (STUART, UK) to prepare homogenate dilution. A serial dilutions of $10^{-2}, 10^{-3}$, $10^{-4}$, and $10^{-5}$ were underwent from homogenate food sample and $0.1 \mathrm{ml}$ dilutions were transferred to Eosin Methylene Blue (EMB, Himedia, India) agar for isolation of $E$. coli and spread by L-shaped glass tube to plates and incubated at $37^{\circ} \mathrm{C}$ for 48 hours then green metallic sheen colonies showing a dark nucleated centre were recorded using colony counter (STUART SCIENTIFIC, UK).

\section{Data analysis}

Data obtained from different food samples were analyzed by using SPSS software version 20.0 and mean bacterial loads of food samples from different sites were compared using one way ANOVA. A p value of $\leq 0.05$ at $95 \%$ confidence interval was considered as statistically significant.

\section{RESULTS}

Socio-demographic data of the street food sellers

In this study, $32(88.9 \%)$ of the vendors were females while $4(11.1 \%)$ were males. Majority vendors $20(55.6 \%)$ were between the age of 18 to 29 , while $12(33.3 \%)$ of them were between 30 and 40 years old and $4(11.1 \%)$ were above 40 years. From the vendors $4(11.1 \%), 8(22.2 \%), 8(22.2 \%)$, $12(33.3 \%)$ and $4(11.1 \%)$ were illiterate, had basic education, elementary school, secondary school and had college diploma, respectively (Table 1).

Knowledge about food safety and personal hygiene of the food sellers

As indicated in table 2, 28(77.8\%) of the street food sellers had a good awareness of food safety, while $8(22.2 \%)$ of the street food sellers had no awareness of food safety. This implies that the vendors contaminate the food items during preparation, handling, transportation, and while they sold. All vendors, 36(100\%), knew hand washing before work reduces the risk of food contamination as well as proper utilization of utensils, proper handling, well cooking of food,

Table 1. Socio-demographic profile of food sellers in the study area

\begin{tabular}{llcc}
\hline Variable & & $\begin{array}{c}\text { Vendors } \\
(\mathrm{N}=36)\end{array}$ & $\begin{array}{c}\text { Percent } \\
(\%)\end{array}$ \\
\hline Sex & Male & 4 & 11.1 \\
& Female & 32 & 89.9 \\
Age & $18-29$ & 20 & 55.6 \\
& $30-40$ & 12 & 33.3 \\
& $>40$ & 4 & 11.1 \\
Marital & Single & 4 & 11.1 \\
status & Married & 32 & 88.9 \\
Educational & Illiterate & 4 & 11.1 \\
status & Basic education & 8 & 22.2 \\
& Elementary school & 8 & 22.2 \\
& Secondary school & 12 & 33.3 \\
& Diploma & 4 & 11.1 \\
\hline
\end{tabular}




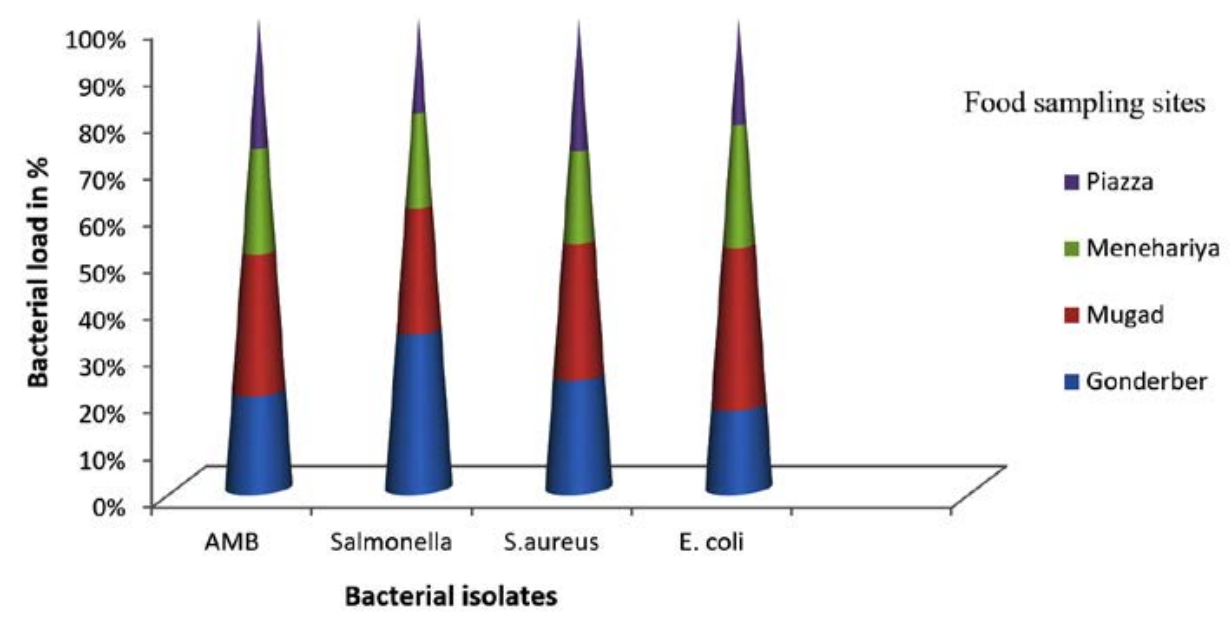

AMB; Aerobic mesophilic bacteria

Fig. 2. Aerobic mesophilic bacteria and isolated species in street vended food items

Table 2. Food safety awareness and handling practices of respondents

\begin{tabular}{|c|c|c|c|}
\hline Parameter & $\begin{array}{l}\text { Vendors } \\
(n=36)\end{array}$ & Frequency & $\begin{array}{c}\text { Percentage } \\
(\%)\end{array}$ \\
\hline \multirow[t]{2}{*}{ Knowledge of food safety } & Yes & 28 & 77.8 \\
\hline & No & 8 & 22.2 \\
\hline \multirow[t]{2}{*}{ Hand washing before work } & Yes & 36 & 100 \\
\hline & No & - & - \\
\hline \multirow[t]{2}{*}{ Handling foods by using gloves } & Yes & 24 & 66.4 \\
\hline & No & 12 & 33.6 \\
\hline \multirow{4}{*}{$\begin{array}{l}\text { Covering of hair when handling } \\
\text { and serving of food } \\
\text { Washing utensils with detergent }\end{array}$} & Yes & 24 & 66.7 \\
\hline & No & 12 & 33.3 \\
\hline & Yes & 36 & 100 \\
\hline & No & - & - \\
\hline \multirow{4}{*}{$\begin{array}{l}\text { Knowledge about hand hygiene } \\
\text { and food-borne diseases } \\
\text { Hand Washing after visiting the toilet }\end{array}$} & Yes & 36 & 100 \\
\hline & No & - & - \\
\hline & Yes & 28 & 77.8 \\
\hline & No & 8 & 22.2 \\
\hline \multirow{2}{*}{$\begin{array}{l}\text { Food selling sites protected from sun, } \\
\text { dust and wind }\end{array}$} & Yes & - & - \\
\hline & No & 36 & 100 \\
\hline Presence of animals or pests (flies etc) & Yes & 36 & 100 \\
\hline around the food selling sites & No & - & - \\
\hline \multirow{2}{*}{$\begin{array}{l}\text { Presence of clear water at the site or } \\
\text { close to the food selling sites }\end{array}$} & Yes & - & - \\
\hline & No & 36 & 100 \\
\hline \multirow[t]{2}{*}{ Sufficient hands washing facilities accessible } & Yes & - & - \\
\hline & No & 36 & 100 \\
\hline \multirow[t]{2}{*}{ vendors handle money while serving food } & Yes & 36 & 100 \\
\hline & No & - & - \\
\hline vendors wash hands after handling money & Yes & - & - \\
\hline before handling food for a second time & No & 36 & 100 \\
\hline \multirow{2}{*}{$\begin{array}{l}\text { The food sellers handle food with uncovered } \\
\text { hands }\end{array}$} & Yes & 30 & 83 \\
\hline & No & 6 & 17 \\
\hline
\end{tabular}


Alem | J Pure Appl Microbiol | 14(3):1845-1854 | September 2020 | https://doi.org/10.22207/JPAM.14.3.23

Table 3. Aerobic mesophilic bacteria and identified bacterial species in some selected food items in $\mathrm{CFUg}^{-1}$.

\begin{tabular}{|c|c|c|c|c|c|c|c|}
\hline & Food items & $\begin{array}{c}\text { No of } \\
\text { sample }\end{array}$ & $\begin{array}{c}\text { AMB } \\
\left(\mathrm{CFU} / \mathrm{g}^{-}\right)\end{array}$ & $\begin{array}{c}\text { Salmonella } \\
\text { (CFU/g) }\end{array}$ & $\begin{array}{l}\text { S.aureus } \\
\text { (CFU/g) }\end{array}$ & $\begin{array}{c}\text { E.coli } \\
\text { (CFU/g) }\end{array}$ & Average \\
\hline \multirow[t]{10}{*}{ Gonderber } & 'Sambussa' & S1 & 755 & 301 & 220 & 234 & 252 \\
\hline & & S2 & 334 & 126 & 96 & 112 & 111 \\
\hline & & S3 & 272 & 47 & 102 & 123 & 91 \\
\hline & 'Bonbolino' & S4 & 434 & 122 & 109 & 203 & 145 \\
\hline & & S5 & 453 & 97 & 89 & 267 & 151 \\
\hline & & S6 & 350 & 85 & 76 & 189 & 117 \\
\hline & 'Ambasha' & S7 & 659 & 101 & 123 & 435 & 220 \\
\hline & & S8 & 422 & 74 & 115 & 233 & 141 \\
\hline & & S9 & 394 & 64 & 96 & 234 & 131 \\
\hline & & Total & 4073 & 1017 & 1026 & 2030 & 1358 \\
\hline \multirow[t]{10}{*}{ Mugad } & 'Sambussa' & S10 & 563 & 107 & 111 & 345 & 188 \\
\hline & & S11. & 515 & 119 & 74 & 322 & 172 \\
\hline & & $\mathrm{S} 12$ & 499 & 66 & 86 & 347 & 166 \\
\hline & 'Bonbolino' & S13 & 1484 & 218 & 473 & 793 & 495 \\
\hline & & S14 & 699 & 122 & 121 & 456 & 233 \\
\hline & & S15 & 585 & 151 & 90 & 344 & 195 \\
\hline & 'Ambasha' & S16 & 596 & 99 & 108 & 389 & 337 \\
\hline & & S17. & 476 & 105 & 93 & 278 & 159 \\
\hline & & S18 & 473 & 96 & 79 & 298 & 158 \\
\hline & & Total & 5890 & 1083 & 1235 & 3572 & 1963 \\
\hline \multirow[t]{10}{*}{ Menehariya } & 'Sambussa' & S19 & 522 & 60 & 97 & 365 & 174 \\
\hline & & S20. & 463 & 94 & 79 & 290 & 154 \\
\hline & & $\mathrm{S} 21$ & 493 & 103 & 88 & 302 & 164 \\
\hline & 'Bonbolino' & S22 & 504 & 107 & 100 & 297 & 173 \\
\hline & & $\mathrm{S} 23$ & 461 & 119 & 85 & 257 & 148 \\
\hline & & S24 & 530 & 66 & 95 & 369 & 186 \\
\hline & 'Ambasha' & $\mathrm{S} 25$ & 587 & 106 & 94 & 387 & 196 \\
\hline & & S26. & 392 & 99 & 99 & 194 & 131 \\
\hline & & $\mathrm{S} 27$ & 402 & 58 & 105 & 239 & 134 \\
\hline & & Total & 4354 & 812 & 842 & 2700 & 1460 \\
\hline \multirow[t]{10}{*}{ Piazza } & 'Sambussa' & S28 & 435 & 105 & 97 & 233 & 145 \\
\hline & & S29 & 310 & 120 & 80 & 110 & 103 \\
\hline & & S30 & 276 & 65 & 89 & 122 & 92 \\
\hline & 'Bonbolino' & S31 & 806 & 108 & 400 & 298 & 270 \\
\hline & & S32 & 490 & 118 & 120 & 252 & 163 \\
\hline & & S33 & 525 & 63 & 92 & 370 & 175 \\
\hline & 'Ambasha' & S34 & 611 & 100 & 121 & 390 & 204 \\
\hline & & S35 & 464 & 75 & 112 & 277 & 155 \\
\hline & & S36 & 460 & 64 & 97 & 299 & 153 \\
\hline & & Total & 4377 & 818 & 1208 & 2351 & 1460 \\
\hline Over all total & & 36 & 18694 & 3730 & 4311 & 10653 & 6240 \\
\hline
\end{tabular}

washing hand after toilet, washing of utensils with detergent and hygiene practices, cleaning and sanitation procedures. From 36 vendors, $24(66.7 \%)$ covered their hair when handling and serving of food, $24(66.7 \%)$ knew the risk of food contamination could be reduced using gloves while handling food, while 12(33.4\%) didn't know using gloves reduce contamination.

From observation of vendors, all vending stall is not protected from dust, wind, sun, as well as animals are available in the vending site, flies can subsequently contaminate other surfaces with 
Table 4. Mean and standard error of bacteriological counts of AMB, Salmonella, S.aureus and E.coli CFUg ${ }^{-1}$ in Woldia town

\begin{tabular}{lcccc}
\hline $\begin{array}{l}\text { Food sampling } \\
\text { sites }\end{array}$ & $\begin{array}{c}\text { Mean and } \\
\text { S.E of AMB }\end{array}$ & $\begin{array}{c}\text { Mean and S.E } \\
\text { of Salmonella }\end{array}$ & $\begin{array}{c}\text { Mean and } \\
\text { S.E of S.aureus }\end{array}$ & $\begin{array}{c}\text { Mean and } \\
\text { S.E of E.coli }\end{array}$ \\
\hline Gonderber & $4.5 \times 10^{2} \pm 5.2 \times 10^{1 \mathrm{a}}$ & $1.5 \times 10^{2} \pm 4.5 \times 10^{1 \mathrm{~b}}$ & $1.1 \times 10^{2} \pm 1.4 \times 10^{1 \mathrm{~b}}$ & $2.1 \times 10^{2} \pm 3.4 \times 10^{1 \mathrm{a} *}$ \\
Mugad & $6.5 \times 10^{2} \pm 1.1 \times 10^{2 \mathrm{a}}$ & $1.2 \times 10^{2} \pm 1.4 \times 10^{1 \mathrm{~b}}$ & $1.4 \times 10^{2} \pm 4.2 \times 10^{\mathrm{b}}$ & $4.0 \times 10^{2} \pm 5.2 \times 10^{1 \mathrm{~b}}$ \\
Menehariya & $4.8 \times 10^{2} \pm 2.1 \times 10^{1 \mathrm{a}}$ & $9.0 \times 10^{1} \pm 7.60^{\mathrm{b}}$ & $9.4 \times 10^{1} \pm 2.72^{\mathrm{b}}$ & $3.0 \times 10^{2} \pm 2.2 \times 10^{1 \mathrm{a}}$ \\
Piazza & $4.9 \times 10^{2} \pm 5.2 \times 10^{1 \mathrm{a}}$ & $9.1 \times 10^{1} \pm 7.97^{\mathrm{b}}$ & $1.3 \times 10^{2} \pm 3.4 \times 10^{1 \mathrm{~b}}$ & $2.6 \times 10^{2} \pm 3.2 \times 10^{1 \mathrm{a}}$ \\
Total & $5.2 \times 10^{2} \pm 3.4 \times 10^{1}$ & $3.1 \times 10^{2} \pm 12.40$ & $1.2 \times 10^{2} \pm 13.66^{\mathrm{b}}$ & $3.0 \times 10^{2} \pm 21.18$ \\
LSD & 34 & 0.67 & 3.00 & 38 \\
\hline
\end{tabular}

Mean values indicated with the same letters are not significant at $P \leq 0.05$; ${ }^{*}$ significant at $P \leq 0.01 ; \mathrm{LSD}$, List Significant Difference; S.E, Standard Error of the mean

Table 5. Incidence of dominant bacteria species in some street-vended foods in Woldia town

\begin{tabular}{lcccc}
\hline Food type & $\begin{array}{c}\text { Number of } \\
\text { isolates } \\
\text { Number }\end{array}$ & $\begin{array}{c}\text { Salmonella } \\
\text { Frequency (\%) }\end{array}$ & $\begin{array}{c}\text { Staphylococcus aureus } \\
\text { Frequency (\%) }\end{array}$ & E.coli \\
\hline 'Sambussa' & 5437 & $1313(24.1 \%)$ & $1219(22.4 \%)$ & $2905(53.5 \%)$ \\
'Bonbolino' & 7321 & $1376(18.8 \%)$ & $1850(25.2 \%)$ & $4095(56 \%)$ \\
'Ambasha' & 5936 & $1041(17.5 \%)$ & $1242(21 \%)$ & $3653(61.5 \%)$ \\
Total & 18694 & $3730(20 \%)$ & $4311(23 \%)$ & $10653(57 \%)$ \\
\hline
\end{tabular}

pathogens from livestock manure by regurgitation, fecal deposition, or mechanical transfer ${ }^{14}$. In all vending site no clean water at the site or close to the site, no washing facilities for hands, vendors didn't wash down their hands in clean water each time before the handling and serving of food and all (100\%) of the street food vendors didn't wash hands after handling money before handling food again and 30 (83\%) of the vendors handle food or money with uncovered hands.

Bacteriological analysis of street-vended foods From four street food vending sites 36 food samples were analyzed from the food items to assess the level of contamination based on aerobic mesophilc bacteria, Salmonella, Staphylococcus aureus and E.coli is indicated in table 3. The study showed that the food samples were contaminated by pathogenic bacteria. Three types of bacterial species were identified from the three kinds of food items. The maximum numbers of Salmonella was seen in 'Sambusa' (S1) from Gonderber and the maximum numbers of S.aureus was observed in 'Bonbolino' (S31) from Piazza. In the case of $E$. coli the highest load was observed in 'Bonbolino' (S13) from Mugad. A total of 18694 bacterial isolates were analyzed from 36 food samples, 5437 bacterial strains were isolated from 'Sambussa', 7321 from 'Bonbolino' and 5936 from 'Ambasha' by using selective media. Among the total bacterial isolates, the dominant bacterial group was E.coli (57\%) followed by Staphylococcus aureus (23\%) and Salmonella (20\%).

From table 4 and Fig. 2, the maximum mean load of aerobic mesophilic bacteria $6.5 \times 10^{2} \pm 1.1 \times 10^{2} \mathrm{CFUg}^{-1}(29.74 \%)$ and Salmonella $1.5 \times 10^{2} \pm 4.5 \times 10^{1} \mathrm{CFUg}^{-1}(33.6 \%)$ were observed from Mugad and Gonderber, respectively. Whereas, the maximum mean load of Staphylococcus aureus $1.4 \times 10^{2} \pm 4.2 \times 10^{1} \mathrm{CFUg}^{-1}(28.59 \%)$ and E.coli $3.9 \times 10^{2} \pm 5.2 \times 10^{1} \mathrm{CFUg}^{-1}(34.1 \%)$ were observed from Mugad. The minimum observed mean load of aerobic mesophilic bacteria from Gonderber, Salmonella from Menehariya, Staphylococcus aureus from Menehariya and E.coli from Gonderber were $4.5 \times 10^{2} \pm 5.2 \times 10^{1} \mathrm{CFUg}^{-1}(20.66 \%)$, $9.0 \times 10^{1} \pm 7.60 \mathrm{CFUg}^{-1}(19.87 \%), 9.4 \times 10^{1} \pm 2.72$ $\mathrm{CFUg}^{-1}(19.49 \%)$ and $2.1 \times 10^{2} \pm 3.4 \times 10^{1} \mathrm{CFUg}^{-1}$ (17.68\%), respectively. Regarding the dominant bacterial species, 10653(57\%) E.coli was observed (Table 5). Statistical significant difference was 
observed in mean value of $E$. coli between 'Sambussa' and 'Bonbolino' at $p \leq 0.05$. However, there was no statistical considerable difference among the mean load of aerobic mesophilic bacteria, Salmonella and Staphylococcus aureus among the four food sampling sites ( $p \leq 0.05)$.

\section{DISCUSSION}

Food items vended in the street plays significant role in low-income countries in order to address the need of food demands of the urban peoples. It is widely utilized by the world's community of millions of people daily due to its accessibility and cheap in price ${ }^{15}$. The present study was conducted to examine the microbial quality of some selected street vended foods sold in four locations in Woldia town.

In this study the socio-demographic characteristics indicated that the majority (89.9\%) of street food sellers were females. A study done in Gondar, Ethiopia reported that $95 \%$ of the vendors were females ${ }^{16}$. Similarly a study done in Jima ${ }^{17}$ also reported the majority (85.5\%) of street food vendors were females. Among 36 venders participated in the current study, $28(77.8 \%)$ of the vendors were washing their hands after toilet which was high compared to findings in Hawassa, Ethiopia $(68.6 \%)^{5}$ and Gondar $(63.3 \%)^{18}$ but it is in line with Addis Ababa, Ethiopia $(80.8 \%)^{19}$ and Jimma, Ethiopia $(77 \%)^{20}$. In this study $66.7 \%$ of the vendors cover their hair while serving and handling foods which was higher than a study reported in Ihiagwa $(12.7 \%)^{21}$.

In the present study, the greater part $(83 \%)$ of the vendors served their customers by handling food with bare hands. A similar study done in Jigjiga City, Ethiopia ${ }^{4}$ indicated $47.62 \%$ of the street food sellers handled food with uncovered hands. The street food sellers can be contaminated by pathogens like Salmonella, $S$. aureus and E.coli and in due course can transmit these food borne disease causing microorganisms to the consumers. This is the fact that those street vended food items are frequently contacted with unhygienic hands of vendors at some point in preparation, handling and serving ${ }^{22}$. World Health Organization ${ }^{23}$ reported those unhygienic food handlers' hands are the main significant vehicle for the transfer of microorganisms from skin, feces and nose to the food.
Overall study indicated that all the food items sold on the street were contaminated with variety of pathogenic microorganisms. As indicated in table 5 , in this study, the mean total count of $\mathrm{AMB}$ was $5.2 \times 10^{2} \pm 3.4 \times 10^{1} \mathrm{CFUg}$ ${ }^{1}$. The load of aerobic mesophilic bacteria is significantly high in 'Bonbolino' mainly due to unhygienic condition of the venders. A similar study in Yaounde-Cameroon ${ }^{24}$, reported there was high count of $A M B$ in the street vended food items. Similarly, a study done in Ambo, Ethiopia ${ }^{25}$ reported that the highest $A M B$ count $\left(2.6 \times 10^{3}\right.$ $\mathrm{CFUg}^{-1}$ ) was observed in street vended foods. Another study done in Jima, Ethiopia ${ }^{17}$ reported a mean aerobic mesophilic bacterial count of $10^{5} \pm 3.16 \mathrm{CFUg}^{-1}$ which was higher than the present study. The mean total count of Salmonella in the study area was $3.1 \times 10^{2} \pm 1.2 \times 10^{1} \mathrm{CFUg}^{-1}$ which was in agreement with a study done in Hawasa, Ethiopia ${ }^{22}$. In Ago-Iwoye, Nigeria ${ }^{26}$, reported only $0.7 \%$ of the food samples were contaminated with Salmonella which was very low compared with the present study.

In the case of Staphylococcus aureus, the mean count in the study area was $1.2 \times 10^{2} \pm 1.4 \times 10^{1}$ $\mathrm{CFUg}^{-1}$. High mean count of Staphylococcus aureus $\left(1.4 \times 10^{2} \pm 4.2 \times 10^{1} \mathrm{CFUg}^{-1}\right)$ was observed in Mugad. A study done in Bahir Dar, Ethiopia ${ }^{3}$ observed high load of Staphylococcus aureus in 'Sambussa' which was in agreement with the findings of the present study. Similarly, a study done in Gonder ${ }^{27}$ $35.54 \%$ of the food samples were contaminated with Staphylococcus aureus. Another study done in Jima, Ethiopia ${ }^{28} 28.2 \%$ of the food samples were contaminated by Staphylococcus aureus which was higher than the frequency of the present study (23\%).

The mean count of E.coli observed in the study area was $2.9 \times 10^{2} \pm 2.1 \times 10^{1} \mathrm{CFUg}^{-1}$ which was higher than the mean count of AMB, Salmonella and S. aureus. High mean load of E.coli count was observed in Mugad $\left(3.9 \times 10^{2} \pm 5.2 \times 10^{1} \mathrm{CFUg}^{-1}\right)$. The load of $E$. coli observed in the present study was not in line with a previous result reported in Gondar $^{29}$. A study done in Bangladesh ${ }^{30}$ a maximum of $4.0 \times 10^{3} \mathrm{CFUg}^{-1}$ E.coli was reported that was not in agreement with the present findings. A similar investigation done in Zimbabwe ${ }^{31}$ reported that $53 \%$ of the food samples were contaminated with 
E. coli which was lower than the present study. The occurrence of high mean count of E.coli in this study area demonstrates a potential high health risk and their occurrence is a suggestion of likely fecal contamination of food or water, water or food handlers and inferior hygienic processing practices $^{8}$.

A high mean count of AMB, Salmonella, $S$. aureus and E.coli suggests contamination of foods due to inappropriate processing, contamination through contact with contaminated utensils and poor personal hygiene of the vendors.

\section{CONCLUSION}

This study revealed the street vended food items were potentially contaminated by the Salmonella, S.aueres and E. coli. Therefore, the occurrence of these microorganisms might be predicted for the presence of potential disease causing microorganisms. Very high bacterial loads from 'Sambussa', 'Bonbolino' and 'Ambasha' food samples suggests a potential health risk to the consumers from the utilization of foods sold in the street in the study area. This indicates poor food handling practice and personal hygiene of the vendors in the street and high risk of food borne infections. To enhance bacterial quality of foods sold in the street by venders providing regular training and creating awareness on food handling and personal hygiene among street food venders as well as consumers is recommended.

\section{ACKNOWLEDGMENTS}

The author acknowledges the study participants and Woldia University for providing necessary facilities and infrastructure to perform the tests.

\section{FUNDING}

None.

\section{ETHICS STATEMENT}

Ethical clearance was obtained from the Ethical Committee of Woldia University. .

\section{DATA AVAILABILITY}

All the necessary data are available in the submitted manuscript.

\section{REFERENCES}

1. Oluwafemi F, Akisanya E, Odeniyi K, Salami W, Sharomi T. Microbiological Quality of Street-Vended Foods and Ready-To Eat Vegetables in Some Nigeria Cities. Afr J Biomed Res. 2013;16:163-166.

2. WHO. World Health Organization global strategy for food safety: safer food for better health. Geneva, Switzerland. 2002.

3. Mesfin A, Mulugeta K, Beye A. Microbiological Quality and Safety of Sambusa and Fried Fish in Bahir Dar, Ethiopia. Food Sci Qua Management. 2015;40:96-107.

4. Tesfaye WB, Yohannes ME, Melese AR, Henok SA. Microbiological Safety of Street Vended Foods in Jigjiga City, Eastern Ethiopia. Ethiop J Health Sci. 2016;26(2):161-170. doi: 10.4314/ejhs.v26i2.10

5. Neja A, Demiss N, Musa A. Prevalence and antimicrobial susceptibility profle of Salmonella and Shigella among food handlers working in food establishment at Hawassa city, Southern Ethiopia. BMC Res Notes. 2019;12(712):1-7. doi: 10.1186/s13104-019-4725-y

6. WHO. Essential Safety Requirements for Street Vended Foods. Food safety unit, Division of food and nutrition. WHO/FNU/FOS 96.7. 1996.

7. Garode AM, Waghode SM. Bacteriological status of Street-Vended foods and Public Health Significance: A Case study of Buldana District, MS, India. ISCA J Biological Sci. 2012;1(3):69-71.

8. Aisha IA, Genitha I. Assessment of Hygienic Practices and Microbiological Quality of Food in an Institutional Food Service Establishment. J Food Proc Technol. 2017;8(8): 1-9.

9. Abdalla MA, Siham ES, Alian, YH, Amel, OB. Food Safety knowledge and practice of street food-vendors in Khartoum city, Sudan. J Vet Sci Anim Husbandry. 2008;47(2):126-136.

10. WHO. Overview of national Codex Committees in the Member States of the WHO South-East Asia Region. 2010.

11. Ayana Z, Yohannis M, Abera Z. Food-borne bacterial diseases in Ethiopia. Acad J Nutr. 2015;4(1):62-76.

12. Ejeta G, Molla B, Alemayehu D, Muckle A. Salmonella serotype isolated from minced meat beef, mutton and pork in Addis Ababa, Ethiopia. Revue Med Vet. 2004;155:547-551.

13. Muleta D, Ashenafi M. Bacteriological profile and holding temperatures of street-vended foods from Addis Ababa. Int J Environ Health Res. 2001;11:95-105. doi: 10.1080/09603120020019683

14. Graczyk TK, Knight R, Gilman RH, Cranfield M. The role of non-biting flies in the epidemiology of human infectious diseases. Microb infect. 2001;3(3):231-235. doi: 10.1016/S1286-4579(01)01371-5

15. Latham MC. Human Nutrition in Tropical Africa. FAO, Rome, Italy. 1997;329-437.

16. Getu D, Samuel S, Mengistu E. Bacteriological Assessment of Some Street Vended Foods in Gondar, Ethiopia. Internet J Food Safety. 2013;15:33-38

17 Reda N, Ketema B, Tsige K. Microbiological quality and safety of some-street-vended foods in Jimma Town, Southwestern Ethiopia. Afr J Microbiol Res. 2017;11(14):574-585. doi: 10.5897/AJMR2014.7326 
18. Legesse Gk, Nishanwork W, Amsalu F. Identifcation of drug-resistant Salmonella from food handlers at the University of Gondar, Ethiopia. BMC Res Notes. 2014;7(545):1-6. doi: 10.1186/1756-0500-7-545

19. Aklilu A, Kahase D, Dessalegn M, Tarekegn N, Gebremichael S, Zenebe S. Prevalence of intestinal parasites, Salmonella and Shigella among apparently health food handlers of Addis Ababa University student's cafeteria, Addis Ababa, Ethiopia. BMC Res Notes. 2015;8(17):1-6. doi: 10.1186/s13104-0140967-x

20. Assefa T, Tasew H, Wondafrash B, Beker J. Contamination of Bacteria and Associated Factors among Food Handlers Working in the Student Cafeterias of Jimma University Main Campus, Jimma, South West Ethiopia. Altern Integr Med. 2015;4(1):1-8. doi: 10.4172/21610711.1000345

21. Okoroafor IE, Ibe Sally NO,Nwanya E, Oyamienlen CS. Knowledge and Practice of Food Hygiene Among Food Vendors in Ihiagwa, Owerri West Local Government Area, Imo State. Texila Int J Public Health. 2019;7(2):113. doi: 10.21522/TIJPH.2013.07.02.Art021

22. Temesgen E, Haimanot T, Derese D, Gebre K. Bacteriological Quality of Street Foods and Antimicrobial Resistance of Isolates in Hawassa, Ethiopia. Ethiop J Health Sci. 2016;26(6):533-542. doi: 10.4314/ejhs.v26i6.5

23. WHO. Health surveillance and management procedures for food handling personnel.WHO technical report series.WHO, Geneva.1989.

24. Nguendo YHB. Eating to Live or Eating to Damage One's Health: Microbiological Risks Associated with Street-Vended Foods in a Subtropical Urban Setting.
Nut Food Sci Int J. 2018;6(4):1-13. doi: 10.19080/ NFSIJ.2018.06.555695

25. Fikadu K. Microbial Quality and Safety of Ready-Made Cooked Foods Catered at Ambo Town Street. Asia Pacific J Edu Art Sci. 2016;3(4): 69-71.

26. Adesetan TO, Mabekoje $\mathrm{O}$ and Bello O. Bacteriological quality of street vended ready-to-eat foods in AgoIwoye, Nigeria: A study of University environment. Int J Microbiol Res Revi. 2017;6(4):225-229.

27. Asefa A, Bimerew M, Tadesse G, Zemichael G, Tsegaye A. Bacteriological Quality Assessment of Selected Street Foods and Their Public Health Importance in Gondar Town, North West Ethiopia. Glob Vet. 2016;17(3):255-264.

28. Shiferaw D, Gadisa N. Microbial Quality and Safety of Bread Sold in Cafeteria, Tea and Bread Shop of Jimma Town, Oromia Regional State, Southwest Ethiopia. J Food Ind Microbiol. 2018;4(1):1-5.

29. Getu D, Samuel S, Mengistu E. Bacteriological Assessment of Some Street Vended Foods in Gondar, Ethiopia. Internet J Food Safety. 2013;15:33-38.

30. Abdullah Al MS, Zobayda FH, Nanda B, Md. Alimul I, Sukumar S. Assessment of Bacteriological Quality of Street Vended Fast Foods and their Antimicrobial Resistance. Int J Current Microbiol App Sci. 2018;7(11):3049-3059. doi: 10.20546/ ijcmas.2018.711.350

31. Raphael K, Clive W, Jeritah T, et al. Microbiological safety of cooked vended foods in an urban informal market: A case study of Mbare Msika, Harare, Zimbabwe. Int J Nutr Food Sci. 2014;3(3):216-221. doi: 10.11648/j.ijnfs.20140303.24 